\title{
The Use of Clobazam as Add-on Treatment in Resistant Epilepsy: Our Retrospective Clinical Data
}

Dirençli Epilepsi Hastalarında Ekleme Tedavisinde Klobazam Kullanımı: Geriye Dönük Klinik Verilerimiz

\author{
(1) Damla Çetinkaya, (1) Seher Naz Yeni \\ Istanbul University-Cerrahpasa, Cerrahpasa Faculty of Medicine, Department of Neurology, Istanbul, Turkey
}

\begin{abstract}
Objective: Patients with drug-resistant focal or generalized epilepsy are important in terms of treatment and polytherapy necessity, adverse effect profiles of drugs, and seizure control difficulties. Clobazam (CLB), which has a lesser sedative effect than other benzodiazepines, is frequently used in different countries. In this study, we aimed to present the results related to the demographic characteristics, adverse effects, and treatment efficacy of patients under CLB treatment.

Materials and Methods: Patients who were followed up in the outpatient clinic of Cerrahpaşa Medical Faculty were screened retrospectively. Sex, age of seizure onset, duration of epilepsy, seizure type, duration of drug use, frequency of seizures before and after CLB, and drug adverse effects were investigated. The decrease in seizure frequency could not be quantitatively evaluated in some patients because the study was retrospective. For this reason, two groups were identified as having a significant reduction in seizure frequency and being seizure-free according to the information provided by the parents and the recorded data.

Results: Forty-one patients with CLB who were followed in the epilepsy clinic were examined. The mean age of 26 male and 15 female patients was 30.30 years. The mean duration of epilepsy was 20.4 years. It was determined that 16 patients were either seizure-free or had intervening rare, mild seizures. There was a significant decrease in seizure frequency in nine patients. Headache was observed in one patient, and sedation and dizziness in two patients.

Conclusion: CLB is especially recommended for add-on therapy in Lennox-Gastaut syndrome. In this study, it was observed that in focal/generalized, idiopathic/ cryptogenic different groups, $39 \%$ of the patients were seizure-free. However, this effect was not lost during the mean follow-up period of 12.2 months. Although the value of this data decreases due to its retrospective nature, the place of CLB in the treatment of focal/generalized epilepsy is important.
\end{abstract}

Keywords: Clobazam, refractory epilepsy, add-on therapy

\section{$\ddot{O} z$}

Amaç: Tedaviye dirençli fokal veya jeneralize epilepsi hastaları epilepsi pratiğinde tedavi ve politerapi gerekliliği, ilaçların yan etki profili ve nöbet kontrolündeki zorluklar açısından önemli bir yer oluşturmaktadır. Diğer benzodiazepinlere göre daha az sedatif etkisi olan klobazam (CLB) farklı ülkelerde sıkça kullanılmaktadır. Biz de bu çalışma ile kliniğimizde takipli olan ve takibimizde iken CLB başlanmış hastaların demografik özellikleri, ilaç yan etkisi, tedavi etkinliği ile ilgili sonuçları sunmayı amaçladık.

Gereç ve Yöntem: Cerrahpaşa Tıp Fakültesi Epilepsi Polikliniği’nde takip edilmekte olan tarafımızca CLB başlanmış hastalar retrospektif olarak tarandı. Cinsiyet, nöbet başlama yaşı, epilepsi süresi, nöbet tipi, ilaç kullanım süresi, CLB öncesi ve sonrası nöbet sıklığı, ilaç yan etkisi araştırıldı. Nöbet sıklığındaki azalma çalışmanın geriye dönük olması nedeniyle bazı hastalarda kantitatif olarak değerlendirilemedi. Bu nedenle ailenin verdiği bilgilere ve dosya verilerine göre nöbetsiz ve nöbet sıklığında anlamlı azalma olarak iki grup tanımlandı.

Bulgular: Epilepsi polikliniğinde takip edilmekte olan ve CLB başlanmış olan 41 hasta incelendi. Yirmi altı erkek 15 kadın hastanın yaş ortalaması 30,30 idi. Ortalama epilepsi süresi 20,4 yıl idi. On altı hastanın ya hiç nöbetsiz ya da araya giren nadir-hafif nöbetler ile izlendiği saptandı. Dokuz hastada nöbet sıklı̆̆ında belirgin azalma olduğu saptandı. Bir hastada baş ağrısı, iki hastada ise sedasyon ve sersemlik yan etki olarak gözlendi.

Sonuç: CLB özellikle Lennox-Gastaut sendromunda ekleme tedavideki yerinden dolayı önerilmektedir. Bu çalışmada fokal/jeneralize, idiyopatik/kriptojenik değişik hasta gruplarında $\% 39$ hastada nöbetsizlik elde edildi. Üstelik 12,2 ay ortalama takip süresi boyunca bu etkinin kaybolmadığı dikkati çekti. Retrospektif niteliği nedeniyle bu verinin değeri azalsa da, CLB'nin fokal/jeneralize epilepsilerde ekleme tedavisindeki yeri önemlidir.

Anahtar Kelimeler: Klobazam, dirençli epilepsi, ekleme tedavisi

Address for Correspondence/Yazışma Adresi: Damla Çetinkaya MD, Istanbul University-Cerrahpasa, Cerrahpasa Faculty of Medicine, Department of Neurology, Istanbul, Turkey

Phone: +905363063021 E-posta: dr.damlacetinkaya@gmail.com ORCID: orcid.org/0000-0001-8511-2260

Received/Geliş Tarihi: 06.11.2018 Accepted/Kabul Tarihi: 20.09.2019

${ }^{\circ}$ Copyright 2020 by Turkish Neurological Society

Turkish Journal of Neurology published by Galenos Publishing House. 


\section{Introduction}

Clobazam (CLB) is a benzodiazepine derivative that has been known since the 1970s, and its use covers a broad spectrum from anxiety disorder to epilepsy. It was first used in Australia in 1970 as a non-sedative agent in the treatment of anxiety, and was used in France to treat epilepsy in $1974(1,2)$. Today, it is used as an antiepileptic in the add-on treatment in many countries. In 2008, it was approved by the United States Food and Drug Administration for use in patients older than two years in the treatment of LennoxGastaut syndrome (LGS) $(2,3)$.

CLB is a 1,5-benzodiazepine derivative as a chemical structure and is different from 1,4-benzodiazepines. The anxiolytic and antiepileptic effects of benzodiazepines are mediated by allosteric binding to the gamma aminobutyric acid (GABA-A) receptor. The sedative effect of 1,5-benzodiazepines is less because of the selectivity of the $\alpha_{2}$ subunit of the GABA-A receptor. At the same time, this selective binding is thought to be associated with less tolerance for the drug $(1,3)$.

Although it was approved as an antiepileptic for LGS, its efficacy is known in the add-on treatment of seizures with focal and generalized onset, and is used for this reason. The adverse effect profile and interactions of drugs used as add-on treatment in patients with resistant epilepsy limit the use of many drugs. It is not sufficient that antiepileptic drugs are effective only, the pharmacokinetic properties, safety, tolerability, and drug-drug interactions of the drugs also play an essential role in treatment selection. Due to the different chemical structure of CLB from other benzodiazepines, the tolerance development and adverse effect profile are lower (2). That it is not available in our country and the difficulties in its provision limit the use of the drug by physicians in add-on treatment.

This study aimed to evaluate the treatment responses of patients who were followed up in our clinic and who were started on CLB as an add-on treatment, and to emphasize add-on treatment in epilepsy practice with our own clinical experience.

\section{Materials and Methods}

The study were approved by the Istanbul University-Cerrahpasa, Cerrahpasa Faculty of Medicine Local Ethics Committee (protocol number: A-15, date: 05.03.2019). Consent form was filled out by all participants.

Patients who were followed up at the epilepsy outpatient clinic of Cerrahpasa Medical Faculty, who were resistant to treatment, and who were started CLB in the outpatient clinic follow-up after admission, were reviewed retrospectively. Patients who were started on CLB in another center were not included in the study. Patients who were not seizure-free with two antiepileptic drugs that were used in adequate doses according to seizure type were accepted as being resistant to treatment (4). As a result of screening, 41 patients with focal or generalized onset epilepsy were detected. The duration of epilepsy, seizure type, epilepsy syndrome, etiologic classification (structural, idiopathic, cryptogenic, genetic), other antiepileptic drugs used together with CLB, the number of antiepileptic drugs used before CLB but discontinued for any reason before CLB, frequency of seizures before and after CLB, epilepsy surgery, and vagal nerve stimulation history were examined. Although the number of drugs currently used by the patients was reported separately, the number of tried drugs before the current treatment was reported as a separate category. The frequency of seizures could be evaluated qualitatively in some patients because of the retrospective nature of the study. Therefore, the patients were divided into three groups as (a) seizure-free, (b) partial-good responders, and (c) non-responders to treatment. According to the medical history taken from the patients and their relatives, patients who indicated a significant but not quantitatively decreased number of seizures after the addition of CLB treatment were accepted as partial responders. Although some patients had seizure chart records, not all patients had enough data. The follow-up of patients continues even though some patients had a short follow-up period of one month because this study was a cross-sectional study in which patient files were scanned.

\section{Results}

The mean age of the 26 male and 15 female patients included in the study was 30.3 (range, 8-53) years. The age of onset of seizures was 9.95 (range, 0-22) years, and the mean duration of epilepsy was 20.4 (range, 2-45) years. Thirty-nine patients had focal, and two had generalized epilepsy seizures. Twenty-two patients had lesions on magnetic resonance imaging (MRI). Nine of these lesions were ischemic gliotic sequelae, four were mesial temporal sclerosis, two were cortical dysplasia, two were heterotopia, one was polymicrogyria, one was ventriculomegaly, one was global cerebral atrophy, one was tuberous sclerosis, and one was compatible with Sturge-Weber syndrome.

Seizure frequency before using CLB was at least once per day in 19 patients, at least once a week in six patients, at least once a month in 14 patients, and at least once a year in one patient. During the follow-up period, seizures were not observed in 16 $(39.02 \%)$ of 41 patients, and a decrease in seizures was observed in nine $(21.9 \%)$. No benefit was observed in $16(39.02 \%)$ patients. The groups with and without seizures (partial responders and nonresponders) were compared in terms of mean duration of epilepsy, seizure frequency before CLB, MRI findings, and the number of antiepileptic drugs used before CLB.

The mean follow-up of the entire patient group was 12.2 (range, 1-36) months $(n=41)$, and the mean follow-up of the seizure-free group was 13.9 (range, 2-36 months) $(n=16)$. The mean number of antiepileptics tried before CLB and discontinued for any reason was 3.08 (range, 1-9) per patient, and the mean number of antiepileptic drugs used in combination with CLB was 2.36 (range, 1-4). In the seizure-free group, the mean number of antiepileptics used and discontinued before CLB was 3 (range, 1-6), and the mean number of antiepileptics used with CLB was 2.12 (range, 1-4).

Before CLB, one to nine different antiepileptic drugs were used and discontinued in all patients. In the seizure-free group, one to four drugs were used before CLB treatment was initiated and discontinued for any reason. Although the causes of discontinuation could not be identified in every patient, failure to control seizures, adverse effects, and tolerance problems were among the reasons for discontinuation of the drugs of the patients. In addition, all patients were using one to four drugs in combination with CLB. There were no patients under CLB monotherapy. The total number 
of antiepileptic drugs used (discontinued and still in use) was 4.68 (range, 2-12) in the entire patient group. The two drugs most combined with CLB were carbamazepine (20 patients) and levetiracetam (19 patients).

When the association between epilepsy duration and treatment responses of the three patient groups was compared, there was no statistically significant difference $(\mathrm{p}=0.480)$.

It was investigated whether the number of antiepileptics used before CLB was a significant parameter in predicting treatment response; however, the number of antiepileptic drugs used before CLB treatment was not predictive in treatment response $(\mathrm{p}=0.834)$. As a result, there was no statistically significant effective parameter in drug response in patients with add-on CLB therapy.

When the adverse effects and tolerance development were examined, adverse effects were observed in three $(7.3 \%)$ of 41 patients, and one patient developed tolerance. There was excessive sleepiness in one patient, dizziness in one patient, and headache in one patient. All of these three patients with adverse effects were in the non-responders group. In the patient with tolerance, the seizures started again with $20 \mathrm{mg} /$ day while without seizures, and seizures ceased when the drug was increased to $30 \mathrm{mg} /$ day.

\section{Discussion}

Although CLB is metabolized in the liver, it does not cause enzyme inhibition or induction (1). In addition, it was shown that the use of CLB add-on treatment did not cause changes in the blood level of other antiepileptics. However, the concentration of CLB in the blood decreases when it used with enzyme-inducing drugs such as carbamazepine, phenytoin, and phenobarbital $(1,5)$. However, it is known that its effectiveness does not decrease (6). Because it is metabolized in the liver, CLB turns into an active metabolite, which is $\mathrm{N}$-desmethylclobazam, and its effectiveness continues. These pharmacokinetic and pharmacodynamic properties facilitate its use in patients with resistant epileptic seizures and are effective in seizure control. CLB-related adverse effects are mostly temporary and show dose-related increases. The most commonly reported adverse effects are somnolence, lethargy, irritability, mood changes, depression, aggression, and dizziness $(2,3,7,8)$.

In this retrospective study, $39.2 \%$ of patients who were followed-up as having refractory epilepsy and who received CLB as an add-on treatment were followed without a seizure for a mean follow-up period of 12.2 months. The importance of monotherapy and treatment with effective dose in the treatment of epilepsy is known, but in the resistant epilepsy group, polytherapy becomes inevitable in most cases. Although most drugs provide seizure control in polytherapy, treatment is discontinued because it is not tolerated due to drug-drug interactions, toxicity, systemic adverse effects, even if it is effective. In the literature, the success of treatment with monotherapy in the refractory epilepsy group was $49.5 \%$, seizure-free status was achieved in $13.3 \%$ of patients in the second add-on treatment, and this success decreased to $3.3 \%$ with the addition of a third antiepileptic drug (9). In the refractory epilepsy group, it was observed that the success rate was low with add-on treatment in patient groups in which seizure control was not achieved with the first drug $(4,9)$.
In this study, it was shown that CLB could be used as a good option in add-on treatment because it is successful in providing seizure-free status in resistant epilepsy and is reliable in terms of its adverse effects profile. In addition, high resistance indicators such as the duration of epilepsy, the number of drugs used before, and the frequency of seizures appeared to be ineffective in response in this group of patients, the majority of which were unknown or focal epilepsy seizures due to structural lesions. However, the small number of patients in the study was evaluated as a limiting factor affecting this result. It has been shown in several studies that $40 \%$ to $75 \%$ of patients using CLB as an add-on treatment have more than a $50 \%$ reduction in seizures $(10,11,12)$. In one study, 417 patients using CLB as an add-on treatment were prospectively evaluated in two outpatient visits, and 151 of the patients (36.2\%) remained seizure-free for 12 months; no treatment response was obtained in 76 patients $(18.2 \%)$ (13). In the present study, it was observed that the rate of seizure-free patients was similar to the literature. In terms of the adverse effect profile, three $(7.3 \%)$ of 41 patients had adverse effects, and this rate also correlates with the literature. In addition, the efficacy did not disappear during the follow-up period, and the follow-up duration of responders and non-responders was found to be similar after CLB. Although the effectiveness of benzodiazepine group drugs in seizure control is high, the development of tolerance limits their long-term use. Another advantage in the use of CLB is that tolerance development is much less than with other benzodiazepines due to the difference in the mechanism of action of this drug. In our data, it was found that tolerance developed in one out of 41 patients, and seizure control was achieved with a dose increase (from $20 \mathrm{mg} /$ day to $30 \mathrm{mg} /$ day).

\section{Conclusion}

Although CLB, which can only be imported, seems effective and safe in terms of drug interaction and adverse effects in polytherapy, the difficulties experienced by physicians and patients in the supply of drugs limit the use of this drug, which has been used safely in various indications abroad for many years. In summary, if CLB were to become available in our country, it seems to be an alternative that can be used more frequently, especially in patients with focal and resistant epilepsy.

\section{Ethics}

Ethics Committee Approval: The study were approved by the Istanbul University-Cerrahpasa, Cerrahpasa Faculty of Medicine Local Ethics Committee (protocol number: A-15, date: 05.03.2019).

Informed Consent: Consent form was filled out by all participants.

Peer-review: Internally peer-reviewed.

\section{Authorship Contributions}

Surgical and Medical Practices: D.Ç., S.N.Y., Concept: D.Ç., S.N.Y., Design: D.Ç., S.N.Y., Data Collection or Processing: D.Ç., S.N.Y., Analysis or Interpretation: D.Ç., S.N.Y., Literature Search: D.Ç., S.N.Y., Writing: D.Ç., S.N.Y.

Conflict of Interest: No conflict of interest was declared by the authors.

Financial Disclosure: The authors declared that this study received no financial support. 


\section{References}

1. Gauthier AC, Mattson R H. Clobazam: A Safe, Efficacious, and Newly Rediscovered Therapeutic for Epilepsy. CNS Neurosci Ther 2015;21:543548.

2. Ng YT, Collins SD. Clobazam. Neurotherapeutics 2007;4:138-144.

3. Pernea M, Sutcliffe AG. Clobazam and its use in epilepsy. Pediatr Rep 2016;8:6516.

4. Kwan P, Schachter SC, Brodie M J. Drug-Resistant Epilepsy. N Engl J Med 2011;365:919-926.

5. Yamamoto Y, Takahashi $\mathrm{Y}$, Imai $\mathrm{K}$, et al. Impact of cytochrome P450 inducers with or without inhibitors on the serum clobazam level in patients with antiepileptic polypharmacy. Eur J Clin Pharmacol 2014;70:1203-1210.

6. Walzer M, Bekersky I, Blum RA, Tolbert D. Pharmacokinetic drug interactions between clobazam and drugs metabolized by cytochrome P450 isoenzymes. Pharmacotherapy 2012;32:340-353.

7. Sugai K. Clobazam as a new antiepileptic drug and clorazepate dipotassium as an alternative antiepileptic drug in Japan. Epilepsia 2004;45(Suppl 8):2025 .
8. Montenegro MA, Arif H, Nahm EA, Resor SR Jr, Hirsch LJ. Efficacy of Clobazam as Add-on Therapy for Refractory Epilepsy. Clin Neuropharmacol 2008;31:333-338.

9. Brodie MJ. Practical Use of Newer Antiepileptic Drugs as Adjunctive Therapy in Focal Epilepsy. CNS Drugs. 2015;29:893-904.

10. Mehndiratta MM, Krishnamurthy M, Rajesh KN, Singh G. Clobazam monotherapy in drug naive adult patients with epilepsy. Seizure 2003;12:226228.

11. Buchanan N. Clobazam in the treatment of epilepsy: Prospective follow-up to 8 years. J R Soc Med 1993;86:378-380.

12. Scott DF, Moffett A. The long-term effect of clobazam as adjunctive therapy in epilepsy. Acta Neurol Scand 1988;77:498-502.

13. Joshi R, Tripathi M, Gupta P, Gupta YK. Effect of clobazam as add-on antiepileptic drug in patients with epilepsy. Indian J Med Res 2014;140:209215. 